Article

\title{
The Use of Parallel Computing to Accelerate Fire Simulations for Cultural Heritage Buildings
}

\author{
Yu-Hsiang Huang $(\mathbb{D}$ \\ Fire Science Department, Central Police University, Taoyuan City 33304, Taiwan; d9613002@mail.ntust.edu.tw \\ Received: 12 October 2020; Accepted: 27 November 2020; Published: 30 November 2020 \\ check for \\ updates
}

\begin{abstract}
This study proposes an optimization design to improve the accuracy of fire risk models by combining the results of the UFSM (Urban Fire Spread Model, Japan) with the United States (US) Fire Simulation Software FDS6.7.3 (Fire Dynamics Simulator, FDS). Using parallel processing, the simulation time was dramatically reduced, and this may assist the risk factor analysis of buildings in a large area. Fire destroyed all seven main structures of the Shuri Castle World Heritage site on 31 October 2019, and this tool may have identified risk factors, which could have been mitigated and potentially prevented the building loss. Other historical buildings may benefit from using this tool to identify their relevant risk factors. This study completed a full-scale simulation of the $76 \mathrm{~m} \times 45 \mathrm{~m} \times 15 \mathrm{~m}$ area, which contained the nine temples, with 6.4 million grids for a simulation time of $600 \mathrm{~s}$ in $45 \mathrm{~h}$. This tool can assist in input-data risk factor analysis and contribute to the improvement of protection technology for cultural heritage buildings.
\end{abstract}

Keywords: tangible cultural heritage; fire risk resilience; FDS; parallel processing; full-scale dimension

\section{Introduction}

The National Disaster Prevention and Response Committee, the Executive Yuan in Taiwan, incorporated historic sites into the disaster prevention and rescue system in 2009. During the years of 2010 to 2013 and 2014 to 2017, the Ministry of Science and Technology carried out the project "An Integrated Study on Disaster Prevention for Cultural Heritage" and the project "Research on the Risk Communication and Resilience of Historic District Fires", respectively. With the support of the Ministry of Science and Technology, the interdisciplinary research team implemented two three-phase integrated plans for disaster prevention technology.

At the beginning of the 21st century, the International Scientific Committee on Risk Preparedness for Cultural Heritage and Disaster Prevention (ICORP) under the United Nations Educational, Scientific, and Cultural Organization (UNESCO) and International Council of Monuments and Sites (ICOMOS) promoted the "endangered heritage" and "blue shield" projects, as well as other initiatives, to combine world heritage preservation with disaster risk management as a global issue. There were several important international conferences on the protection of cultural heritage in recent years with focus on post-disaster reconstruction, including the "Sendai Declaration" of the Third World Conference on Disaster Risk Reduction (WCDRR) in 2015 [1], the "Sendai Framework for Disaster Risk Reduction 2015-2030", and the Scientific Symposium of the ICOMOS 2016 Conference. Since monuments and historical buildings that have been repeatedly damaged by fires, earthquakes, and/or floods are hard to recover, all countries in the world are promoting the disaster prevention and reduction of cultural assets to protect tangible cultural heritage, especially with respect to preventing fires. Taiwan is no exception and will break through the technical threshold to enhance the breadth and precision of fire scenario simulation [2]. 


\section{Protection of Tangible Cultural Heritage}

\subsection{Sendai Declaration and Sendai Framework for Disaster Risk Reduction 2015-2030}

The third United Nations (UN) World Conference on Disaster Reduction was held in Sendai, Japan in March 2015. Several important issues were discussed at the conference, including disaster prevention of cultural heritage, disaster reduction via technology, and integrated risk management of government and community [3]. The "Sendai Declaration" and the "Sendai Framework for Disaster Risk Reduction 2015-2030" were published, and four priorities for action were proposed as follows:

a. Understanding disaster risk;

b. Strengthening disaster risk governance to manage disaster risk;

c. Investing in disaster risk reduction for resilience;

d. Enhancing disaster preparedness for effective response, and to "build back better" in recovery, rehabilitation, and reconstruction [4].

Disasters related to tangible cultural heritage include earthquakes, fires, windstorms, and manmade disasters such as war and arson. In September 2017, India's National Disaster Management Guidelines for Cultural Heritage Sites and Precincts defined the term "disaster" as a serious damage to the extensive operation of the community or social human, material, economic, or environmental losses and impacts, exceeding the capacity of the affected communities or the society's own resources [5].

\subsection{The Research Object: Tangible Cultural Heritage in Taiwan}

In 2016, Cultural Heritage Preservation Act was amended according to the preservation classification method of UNESCO, which divides cultural heritage into tangible and intangible. Tangible cultural heritage is divided into nine categories: historic sites, historical buildings, memorial buildings, settlement buildings, archaeological sites, historical sites, cultural landscapes, antiquities, and natural landscapes. These objects are mainly immovable monuments, historical buildings, and movable antiquities. Related research topics addressed internationally are shown in Table 1.

Table 1. Tangible cultural heritage protection topics. ICOMOS, International Council of Monuments and Sites.

\begin{tabular}{ll}
\hline \multicolumn{1}{c}{ Risk resilience } & $\begin{array}{l}\text { The ability of a system to anticipate, absorb, } \\
\text { accommodate, or recover from disaster in a timely and } \\
\text { efficient manner [6,7]. }\end{array}$ \\
\hline Harmonization & $\begin{array}{l}\text { For cultural heritage, the function of harmonization is not } \\
\text { limited to the final education and training; rather, } \\
\text { the concept should be included in the initial stage of } \\
\text { risk identification. }\end{array}$ \\
\hline Reconstruction and building back better [4] & $\begin{array}{l}\text { Heritage and Democracy was the central theme of the } \\
\text { 19th ICOMOS Scientific Symposium, 2017. In addition to } \\
\text { the formal considerations for the post-disaster } \\
\text { reconstruction, the original materials, construction } \\
\text { methods, and participation in the local community } \\
\text { should be reproduced. }\end{array}$ \\
\hline $\begin{array}{l}\text { The application of science and technology in the } \\
\text { management of cultural heritage disaster risk, including } \\
\text { the identification of historical materials and components, } \\
\text { three-dimensional (3D) scanning technology, risk } \\
\text { prediction and assessment, and building disaster } \\
\text { resistance assessment (e.g., earthquake and fire), } \\
\text { especially with fire as a research focus. }\end{array}$ \\
\hline
\end{tabular}




\section{Post-Disaster Assessment}

This study refers to India's National Disaster Management Guidelines for Cultural Heritage Sites and Precincts and combines the risk reduction of interactions among hazards, exposures, and vulnerabilities to reduce the probability of event occurrence with negative consequences, as shown in Figure 1 [5].

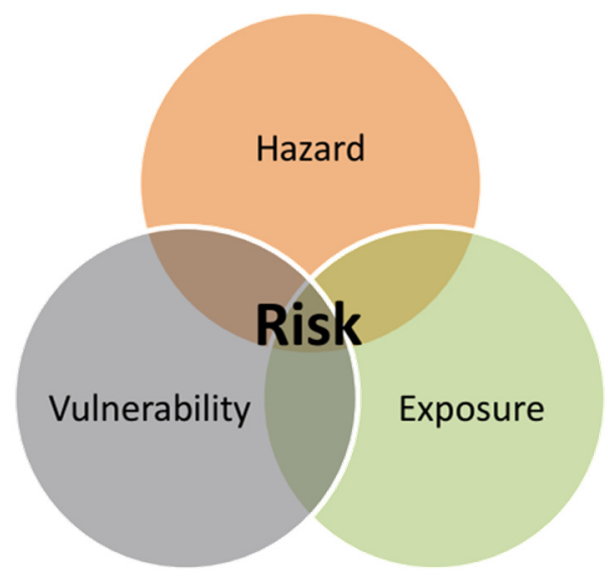

Figure 1. Relationship among hazard, vulnerability, and exposure.

\subsection{Tangible Cultural Heritage Fires in Taiwan}

During the 47 years from 1970 to 2017, there were 43 cases of tangible cultural heritage fires affecting historic buildings, monuments, and cultural landscapes in Taiwan. This represents an average of almost one fire disaster at a historical site per year in the past 50 years. Additionally, in the past 10 years, fires happened more frequently with a twofold growth rate, as shown in Table 2. The cause of the destruction of tangible cultural heritage sites is related to natural disasters and manmade disasters. Among these cases, multipoint fires caused by earthquakes or human factors such as arson caused the largest proportion of the damage to tangible cultural heritage sites.

Table 2. List of Taiwan tangible cultural heritage fires ([9-11], \& organized in this study).

\begin{tabular}{|c|c|c|c|c|c|c|}
\hline \multicolumn{2}{|c|}{ Year } & \multirow{2}{*}{ Time } & \multirow{2}{*}{ Case } & \multirow{2}{*}{ City } & \multirow{2}{*}{ Cause } & \multirow{2}{*}{ Category } \\
\hline Occurred & Registered & & & & & \\
\hline 2008 & 2018 & 2:00 & Luchou Lee Family estate & New Taipei City & Intentional & Monument \\
\hline 2008 & 2007 & 3:00 & Dihua Street & Taipei City & EM & Historic Arch. \\
\hline 2009 & 2005 & 22:46 & $\begin{array}{l}\text { Chiang Kai-Shek } \\
\text { Shilin Residence }\end{array}$ & Taipei City & EM & Monument \\
\hline 2010 & 2003 & 15:00 & Taisugar Taipei warehouse & Taipei City & Careless & Monument \\
\hline 2010 & 2004 & 2:36 & Shueijiaoshe Cultural Park & Tainan City & Intentional & Monument \\
\hline 2010 & 1985 & 0:00 & Miaoli Wen-Chang Temple & Miaoli County & EM & Monument \\
\hline 2012 & 1985 & 2:00 & Fengshan Longshan Temple & Kaohsiung City & Intentional & Monument \\
\hline 2013 & 2015 & $21: 22$ & $\begin{array}{l}\text { Fengyuan Forestry Bureau } \\
\text { Dormitory Group }\end{array}$ & Taichung City & Unknown & Historic Arch. \\
\hline 2013 & 2005 & 3:00 & $\begin{array}{l}\text { Shuili Checheng } \\
\text { Dormitory Group }\end{array}$ & Nantou County & Intentional & Historic Arch. \\
\hline 2013 & 2003 & $0: 23$ & Puzi Pei-Tian Temple & Chiayi County & Careless & Monument \\
\hline 2013 & 2003 & $7: 40$ & $\begin{array}{l}\text { Zhengbin Building of } \\
\text { Fishermen's Association }\end{array}$ & Keelung City & EM & Historic Arch. \\
\hline 2014 & 2014 & 5:00 & $\begin{array}{l}\text { Keelung Harbor West } \\
\text { Second Warehouse }\end{array}$ & Keelung City & EM & Historic Arch. \\
\hline
\end{tabular}


Table 2. Cont.

\begin{tabular}{|c|c|c|c|c|c|c|}
\hline \multicolumn{2}{|c|}{ Year } & Time & Case & City & Cause & Category \\
\hline 2016 & 2006 & $12: 20$ & $\begin{array}{c}\text { Former South Garden } \\
\text { Japanese-style dorm. group }\end{array}$ & Taipei City & Other heat & Monument \\
\hline 2016 & 2000 & $5: 30$ & Lugang Fengshan Temple & Changhua County & Careless & Monument \\
\hline 2016 & 2007 & $12: 59$ & $\begin{array}{c}\text { Taiwan Railways } \\
\text { Dormitory group, Lane 38, } \\
\text { Zhengzhou Road }\end{array}$ & Taipei City & Intentional & Monument \\
\hline 2016 & 2014 & $5: 11$ & $\begin{array}{l}\text { Affiliated buildings of } \\
\text { Taichung City Hall }\end{array}$ & Taichung City & Careless & Historic Arch. \\
\hline 2016 & 2016 & $17: 06$ & $\begin{array}{l}\text { Taichung Train Station } \\
\text { Dormitory group }\end{array}$ & Taichung City & Careless & Monument \\
\hline 2017 & 2013 & $20: 13$ & $\begin{array}{l}\text { Yangmingshan American } \\
\text { Military Housing }\end{array}$ & Taipei City & Careless & Cultural Arts \\
\hline 2017 & 1985 & $14: 00$ & Changhua Guandi Temple & Changhua County & Careless & Monument \\
\hline
\end{tabular}

* Intentional arson cases occurred six times in 2016/EM, electrical malfunction.

The fires at tangible cultural heritage sites in Taiwan, as presented in Table 2, have contributed positive changes in the past decade to cooperation between public and private sectors, as well as research institutes, thereby promoting the relevant cultural heritage protection act similar to that in Japan, South Korea, and other countries that value cultural heritage protection. For example, India, which has 36 UNESCO World Heritage Sites, has also joined the ranks of cultural heritage protection, publishing the book of National Disaster Management Guidelines for Cultural Heritage Sites and Precincts on 22 September 2017, as shown in Table 3. The purpose of post-disaster study is to understand how to minimize the damage caused by fire and to realize the effect of non-statutory fire safety equipment (functional) through various scenarios of fire simulations on heat propagation. This study seeks not only to develop technologies for protecting tangible cultural heritage through risk identification, but also to promote the communication of such safety awareness with local people.

Table 3. Evolution of cultural heritage acts in Japan, South Korea, India, and Taiwan ([11], organized in this study).

\begin{tabular}{|c|c|c|c|c|}
\hline Country & Year & Evolution Disaster & \multicolumn{2}{|c|}{ Change } \\
\hline Japan & 1949 & Hōryū-ji Fire & $\begin{array}{l}\text { Cultural Properties } \\
\text { Protection Act }\end{array}$ & $\begin{array}{c}\text { January } 26 \\
\text { Cultural Heritage Fire } \\
\text { Safety Day }\end{array}$ \\
\hline South Korea & 2008 & Namdaemun Fire & $\begin{array}{l}\text { Cultural Heritage } \\
\text { Protection Act }\end{array}$ & $\begin{array}{c}\text { February } 10 \\
\text { Cultural Heritage Fire } \\
\text { Safety Day }\end{array}$ \\
\hline \multirow{2}{*}{ Taiwan } & 1999 & September 21 Earthquake & $\begin{array}{c}\text { Major Disaster Response } \\
\text { Measures for Monuments and } \\
\text { Historic Buildings }\end{array}$ & $\begin{array}{c}\text { September } 21 \\
\text { Disaster prevention day }\end{array}$ \\
\hline & 2016 & $\begin{array}{l}\text { A series of fires and } \\
\text { Intentional damage }\end{array}$ & $\begin{array}{l}\text { Cultural Heritage } \\
\text { Preservation Act }\end{array}$ & $\begin{array}{l}\text { September, Cultural } \\
\text { Heritage Disaster } \\
\text { prevention month }\end{array}$ \\
\hline
\end{tabular}




\subsection{Fire Simulation Steps for Tangible Cultural Heritage}

A building group, such as the Beigang Chaotian Temple with nine halls, is a better research object than a single historic architecture for modeling fire spread. Another way in which the Beigang Chaotian Temple differs from previous research objects in major cities is that it is located in Yunlin County, where the financial and human resources are lower compared with the six other cities in Taiwan. Furthermore, it suffered a historical fire in 1995, where it survived serious damage. The hope was to propose a simple disaster prevention and reduction strategy with a risk-informed approach [12] to fill the urban-rural gap and to enhance the self-help ability of historic buildings [13].

The first step was to establish a single-architecture type Fire Dynamics Simulator (FDS) model to simulate various fire situations with multipoint fires generated due to electrical malfunction, arson, spread, or large-scale earthquakes. In addition, fire-fighting water curtains and water-spraying guns were added to simulate the situations mentioned above.

The second step was to build the FDS model to represent a street of houses in a historical block to identify risk factors and establish risk maps.

Lastly, the fire safety model of the historical building group was established, and it was combined with the urban fire spread model (UFSM) to verify the resilience of tangible cultural heritage. We sought to explore whether functional fire safety equipment can effectively block the propagation of fire between buildings and limit damage, thereby improving the overall resilience against the fire.

\section{Research Methods and Applications}

Taiwan also faces the difficulties mentioned above. The tangible cultural heritage sites and the important cultural relics are mainly composed of wood and masonry. Resistance to natural and manmade disasters is mostly insufficient, especially to fire caused by earthquakes. The research method of this article included analyzing the data collected from field post-disaster investigations following the fire in 1995, as well as conducting computer simulations with computational fluid dynamics (CFD). Therefore, this study discusses the fire risk caused by earthquakes toward tangible cultural heritage sites with a performance verification of resilience in a worst-case scenario.

\subsection{Risk Assessment and Field Survey}

Shen-Wen Chien (2013), Professor at the Central Police University in Taiwan, proposed the concept of quantifying the risk of historical building fires. Among the potential hazard factors to building structure, the fire risk is the most serious. Thus, the result of fire simulations can be useful suggestions such as the digital technology application presented by ICOMOS in 2017. This study selected a representative tangible cultural heritage site (Beigang Chaotian Temple) to conduct a survey of the building environment, exploring the fire risk factors and safety factors, including the allowed number of people in the building, usage of buildings, daily management and maintenance, emergency response and rescue plan, roadway width, opening position and structure materials of the building, and spacing between adjacent buildings, to carry out a simulation analysis of disaster prevention. By comparing the field survey with the literature data, the parameters of the subsequent computer simulation were deemed reasonable and consistent with the situation.

The preliminary field investigation of the case study was completed on 28 December 2018, which involved not only building a model with appropriate materials but also personally interviewing the temple staff who participated in the initial emergency rescue at the time of the 1995 fire.

\subsection{Computer Simulation}

The use of programming, numerical calculations, and fire simulation software is an international research trend in fire engineering. The main methods are summarized below.

The Urban Fire Spread Model (UFSM) [14], which was developed by the research laboratory of Professor Tanaka at Kyoto University in Japan, was applied to predict the impact of fire in the 
source building on adjacent buildings. It is mainly divided into two parts: construction burning and extension burning, as shown in Figure 2. Is involves evaluating the heat or flames emitted from the wall, and calculating the change in temperature and concentration of chemical materials in the building according to its shape parameters, its spacing with adjacent buildings and its structure materials. The heat via radiation or convection from the flame of the building and the effect of the flying fire are examples of predictive methods for the spread of fire in a group of buildings [15].

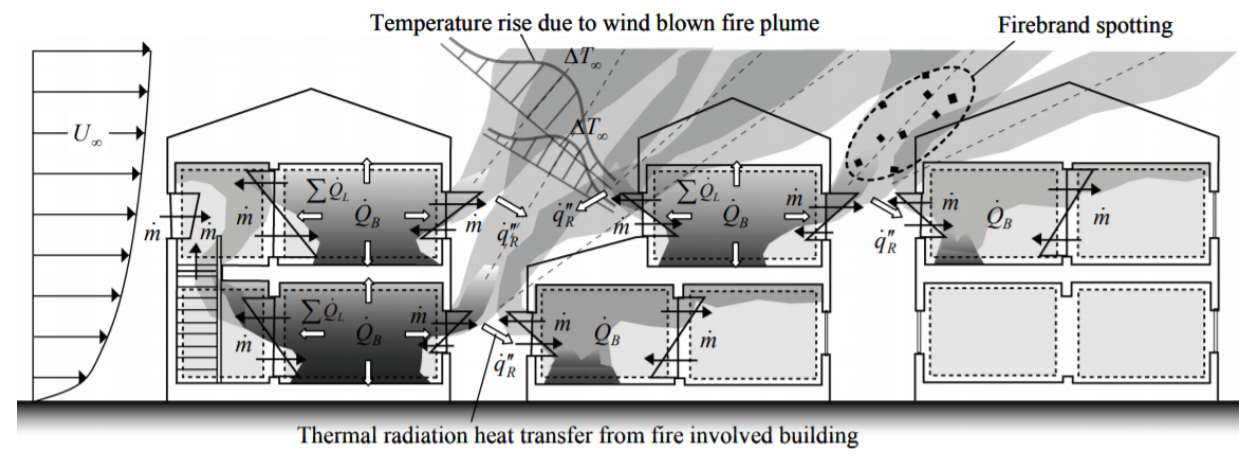

Figure 2. Urban Fire Spread Model (UFSM) (Tanaka, 2008) [14].

Hasemi Yuji (2013), Professor of Waseda University in Japan, applied the FDS (Fire Dynamics Simulator) to simulate situations of fire spread along traditionally preserved streets and fire damage after earthquakes; the results showed that burning for $2 \mathrm{~h}$ after an earthquake was the worst-case scenario, leading to an extension fire with increased burning speed.

This study used FDS as a numerical analysis tool to construct a three-dimensional fire simulation scenario and evaluate data such as temperature, visibility, $\mathrm{CO}$ concentration, and smoke flow, which are useful to explore the fire risk to tangible culture heritage sites and their occupants [16]. This article took temperature as an example representing the most important risk factor for historical temples to show the advantage of full-scale simulations.

\subsection{Mesh for the FDS Parallel Process}

FDS was used to divide the research space into small grids for calculation. Grids with different thicknesses or dimensions significantly affect the accuracy of the calculation results. The $x y z$ ratio of grids varies widely, leading to errors in the calculation result even when using very thin grids. Thus, it is recommended to cut the simulation space into a number of numerical grids close in shape to a cube (i.e., close to an $x y z$ ratio of 1:1:1), as shown in Figure 3. The building was cut into six meshes, and each mesh was assigned to a central processing unit (CPU) for calculation. This study focused on the technical threshold of FDS for simulating large spaces, such as historical groups of buildings at tangible cultural heritage sites, handling both the efficiency and the accuracy of the simulation. The concept of resource sharing in parallel processed involves combining the computing power of multiple cores, thereby reducing the amount of data processed by a single computer via data exchange between computers in adjacent meshes. Then, all the processed data are transferred to the host computer for consolidation, as would happen in calculations using a single super computer [17]. The background details related to the mesh, grids, CPUs, and simulation can be seen in Table 4. Each mesh involved $1,012,500$ to 1,350,000 grids, and each CPU had a $3.6 \mathrm{GHz} /$ hexa core, with $8 \mathrm{~GB}$ random-access memory (RAM), used for the full-scale fire simulation. The total number of grids in the six meshes was $6,412,500$. 


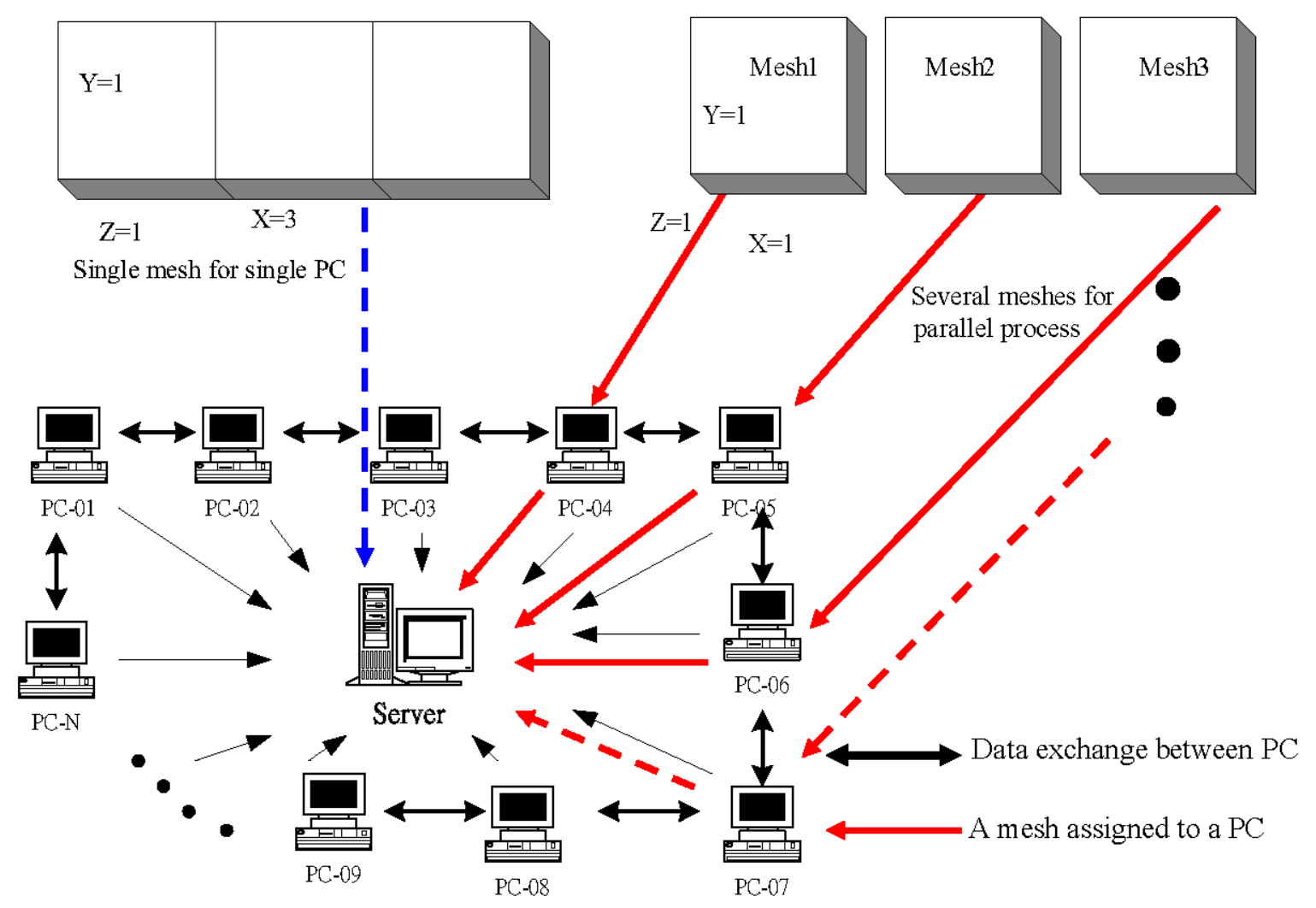

Figure 3. Parallel process diagram of FDS [18].

Table 4. Background details of the simulated temple. CPU, central processing unit; FDS, Fire Dynamics Simulator.

\begin{tabular}{ccc}
\hline & Full-Scale & Specific Narrowing Ranges \\
\hline Space dimension & $76 \mathrm{~m} \times 45 \mathrm{~m} \times 15 \mathrm{~m}$ & $32 \mathrm{~m} \times 14 \mathrm{~m} \times 15 \mathrm{~m}$ \\
Roof height & $13 \mathrm{~m}$ & $13 \mathrm{~m}$ \\
Area & $72 \mathrm{~m} \times 44 \mathrm{~m}=3168 \mathrm{~m}^{2}$ & $32 \mathrm{~m} \times 14 \mathrm{~m}=448 \mathrm{~m}^{2}$ \\
Grids/Size & $6,412,500 / 20 \mathrm{~cm} \mathrm{cube}$ & $840,000 / 20 \mathrm{~cm} \mathrm{cube}$ \\
Initial temperature & $20{ }^{\circ} \mathrm{C}$ & $20^{\circ} \mathrm{C}$ \\
CPUs & 6 & Single \\
FDS simulation time & $600 \mathrm{~s}$ & $600 \mathrm{~s}$ \\
CPU Time & $45 \mathrm{~h}$ & $33 \mathrm{~h}$ \\
\hline
\end{tabular}

The brief results of the two designs involving full-scale buildings and narrow ranges in a single house show that the performance in terms of space dimension, area, and CPUs of the parallel design was much better, except for the CPU time which was similar at $45 \mathrm{~h}$, as shown in Figure 4.

The temperature profile of the full-scale simulation (nine temples) was much clearer than the local-scale range of the FDS. In fact, taking $45 \mathrm{~h}$ to finish a $600 \mathrm{~s}$ simulation with 6.4 million grids is very helpful for researchers or designers pursuing ideal input data modification.

Therefore, the computing time is much shorter than that of a personal computer, and the actual results can overcome the limitation of the space range to achieve full-size simulations of large spaces while taking into account the research results of precision, validity, and range. 


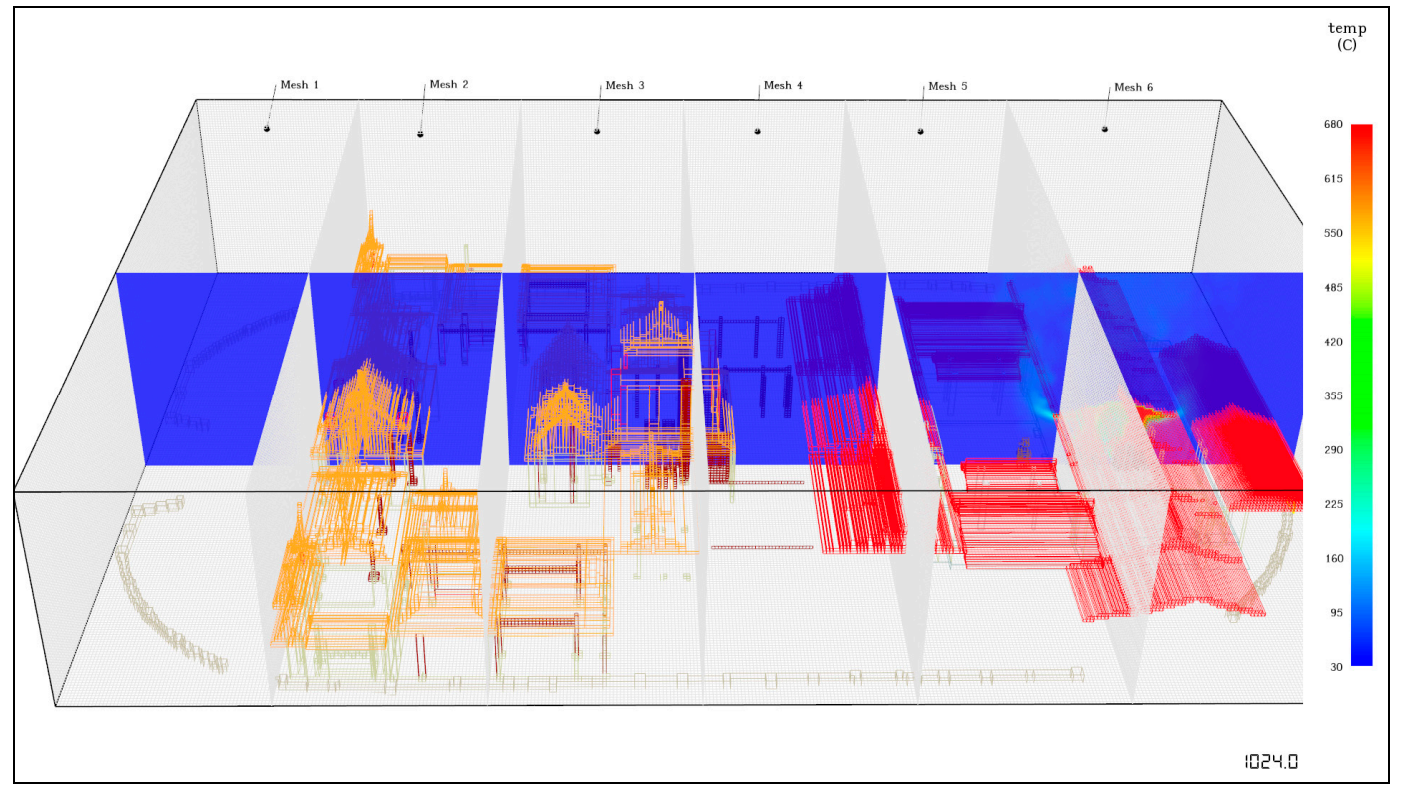

Figure 4. Full-scale building cut into six meshes assigned to six CPUs for parallel processing in Pyrosim.

The input data of FDS parallel processes are described below for six CPU design scenarios with $6,412,500$ grids, obeying the regulation of a Poisson solver based on fast Fourier transforms (FFTs); each grid's dimensions followed the form of $2^{l} 3^{m} 5^{n}$, where $l, m$, and $n$ are integers [19]. The instructions for the input data of the six CPUs were as follows with the definition of grid size and dimensions of six meshes:

CPU 1.

$\&$ MESH ID $=$ 'Mesh1', IJK $=60,225,75$, XB $=28.0,40.0,14.0,59.0,0.0,15.0$, MPI_PROCESS $=$ 0/GRIDs $=1,012,500=[(40.0-28.0) / 0.2] \times[(59.0-14.0) / 0.2] \times[(15.0-0.0) / 0.2] ;$

CPU 2.

$\&$ MESH ID $=$ 'Mesh2', IJK $=60,225,75, \mathrm{XB}=40.0,52.0,14.0,59.0,0.0,15.0$, MPI_PROCESS $=1$ /GRIDs $=1,012,500=[(52.0-40.0) / 0.2] \times[(59.0-14.0) / 0.2] \times[(15.0-0.0) / 0.2] ;$

CPU 3.

\&MESH ID = 'Mesh3', IJK = 60,225,75, XB = 52.0,64.0,14.0,59.0,0.0,15.0, MPI_PROCESS = 2/GRIDs $=1,012,500=[(64.0-52.0) / 0.2] \times[(59.0-14.0) / 0.2] \times[(15.0-0.0) / 0.2] ;$

CPU 4.

$\&$ MESH ID $=$ 'Mesh4', IJK = 60,225,75, XB = 64.0,76.0,14.0,59.0,0.0,15.0, MPI_PROCESS = 3/GRIDs $=1,012,500=[(76.0-64.0) / 0.2] \times[(59.0-14.0) / 0.2] \times[(15.0-0.0) / 0.2] ;$

CPU 5.

$\&$ MESH ID $=$ 'Mesh5', IJK = 60,225,75, XB = 76.0,88.0,14.0,59.0,0.0,15.0, MPI_PROCESS $=$ 4/GRIDs $=1,012,500=[(88.0-76.0) / 0.2] \times[(59.0-14.0) / 0.2] \times[(15.0-0.0) / 0.2] ;$

CPU 6.

\&MESH ID = 'Mesh6', IJK = 80,225,75, XB = 88.0,104.0,14.0,59.0,0.0,15.0, MPI_PROCESS = 5/GRIDs $=1,350,000=[(104.0-88.0) / 0.2] \times[(59.0-14.0) / 0.2] \times[(15.0-0.0) / 0.2]$.

The fire simulation calculation of a single computer is limited by the size of the space, thereby only presenting the fire phenomenon in a limited space. The data calculation involves a single mesh for a single CPU, as shown by the blue dotted line in Figure 3. The parallel process diagram of FDS instead featured six meshes assigned to six CPUs to complete the $76 \mathrm{~m} \times 45 \mathrm{~m} \times 15 \mathrm{~m}$ full-scale simulation of the building, as shown by the red line in Figures 3 and 4 [20].

The left side of Figure 5 shows the limited range of a fire simulation, whereby the temperature near the ignition source can reach $650^{\circ} \mathrm{C}$, which is much higher than the temperature value safe for human life of $60^{\circ} \mathrm{C}$, shown as the black area. The critical temperature of wood $\left(260^{\circ} \mathrm{C}\right)$ was also 
reached, presenting the possibility of igniting adjacent wooden objects and structures of tangible cultural heritages made of wood. The temperature near the fire source could reach $650{ }^{\circ} \mathrm{C}$ after ignition in the main hall for $600 \mathrm{~s}$. However, it is not possible to know whether the temperature in other parts of the main hall reached the dangerous wood critical temperature of $260^{\circ} \mathrm{C}$. On the right side of Figure 5, a temperature of $670{ }^{\circ} \mathrm{C}$ was reached in $10 \mathrm{~min}$ due to a general fire source with damage to adjacent buildings. The full-area simulation on the right side of Figure 5 shows that the temperature of the main hall could reach $670{ }^{\circ} \mathrm{C}$ and expand from the opening door, as shown by the black curve. It is helpful to understand the full picture of the simulation for the whole area before planning the design of a protective strain mechanism.

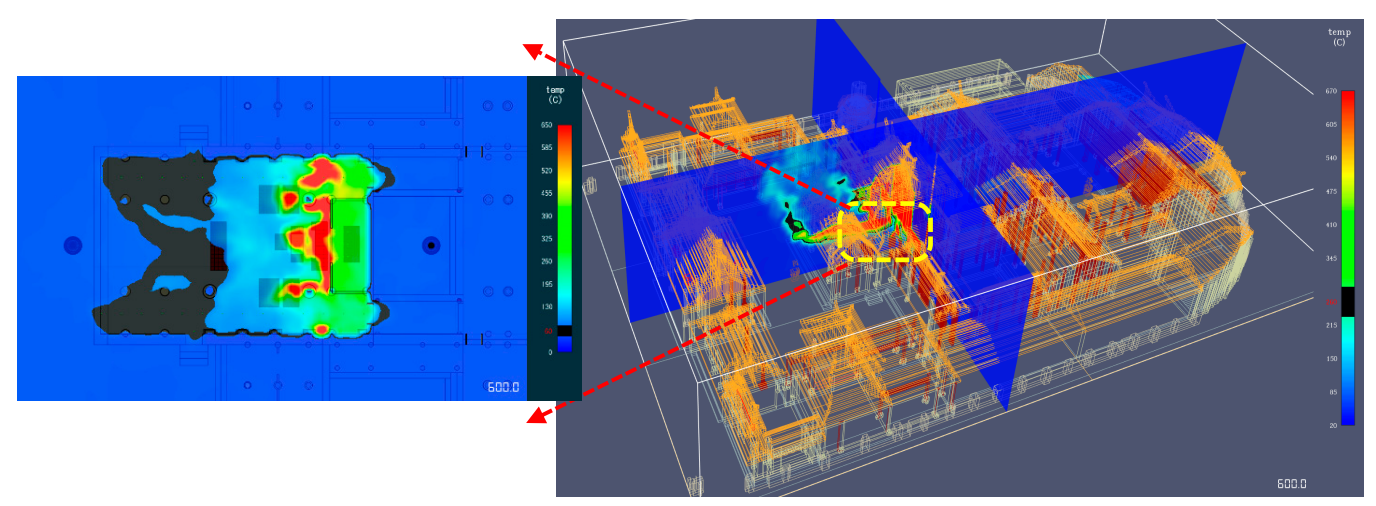

Figure 5. Temperature profile of local-scale [21] and full-scale (nine temples) FDS simulations.

\section{Concluding Remarks}

In the past 50 years, an average of one tangible cultural heritage fire occurred in Taiwan every year. However, in the past two decades, this has doubled to two fires per year. It is obvious that the high degree of social development is directly proportional to the destruction of tangible cultural heritage sites. Thus, protection measures for heritage sites are even more urgent.

It should be a practical research direction to integrate the simulation technology of FDS and the Japan Urban Fire Spread Model (UFSM) for large-scale fire (spread fire) simulation to have promising results. This allows improving the protection technology for tangible cultural heritage sites in Taiwan.

1. The simulation of full-scale building fires is more valuable than the simulation of specific narrow ranges, because it provides an evaluation of the whole area in a fire scenario, especially for fire spread among groups of building as occurred in the Shuri Castle fire on 31 October 2019. This study completed a full-scale simulation replicating a real area of $76 \mathrm{~m} \times 45 \mathrm{~m} \times 15 \mathrm{~m}$ with nine temples by 6.4 million grids, with a calculation of $600 \mathrm{~s}$ simulation time in $45 \mathrm{~h}$. This surpasses the results from previous cases and provides a better research method in the full-scale range, thereby validating the fire simulation for tangible cultural heritage sites for their protection in this field.

2. A temperature of $670{ }^{\circ} \mathrm{C}$ could be reached in $10 \mathrm{~min}$ due to a general fire source with damage to adjacent buildings. Historical buildings are dominated by wooden structures, and this study highlighted $10 \mathrm{~min}$ as the critical time for an emergency response.

3. Historic buildings may be exempt from the requirements of automatic fire extinguishing systems and fire safety regulations in order to keep their original appearance. However, if there is an identification or risk via a communication exercise at this critical time, the 119 automatic notification system can be linked to a fire alarm system. The golden response time can, thus, still be achieved, and the fire can be limited to the initial room, especially for historical temples without proper security measures.

Funding: This research received no external funding.

Conflicts of Interest: The author declares no conflict of interest. 


\section{References}

1. UNESCO. Sendai Declaration of the Third World Conference on Disaster Risk Reduction; United Nations: Sendai, Japan, 2015. Available online: https://www.unisdr.org/files/45069_proceedingsthirdunitednationsworldc.pdf (accessed on 21 August 2019).

2. UNESCO. Strategy for Reducing Risks from Disasters at World Heritage Properties; United Nations: Christchurch, New Zealand, 2007. Available online: https://whc.unesco.org/archive/2007/whc07-31com-72e.pdf (accessed on 14 February 2020).

3. UNESCO. Harmonizing Actions to Reduce Risks for Cultural Heritage in Asia and the Pacific; United Nations: Penang, Malaysia, 2015.

4. Sendai Framework for Disaster Risk Reduction 2015-2030. Available online: https://www.unisdr.org/we/ coordinate/sendai-framework (accessed on 15 February 2020).

5. National Disaster Management Guidelines for Cultural Heritage Sites and Precincts; National Disaster Management Authority: New Delhi, India, 2017.

6. ICORP. Heritage and Resilience: Issues and Opportunities for Reducing Disaster Risks; United Nations: Geneva, Switzerland, 2013.

7. IPCC. Managing the Risks of Extreme Events and Disasters to Advance Climate Change Adaptation; Cambridge University Press: Cambridge, UK, 2012.

8. ICOMOS 2017 Annual Report; ICOMOS: Paris, France, 2017.

9. Feng, W.-H. Historical District Fire Risk Analysis and Fire Spread Models-A Case Study on Taipei DiHua Street. Msater's Thesis, Central Police University, Taoyuan City, Taiwan, 2016.

10. Chen, J.L.; Wen, I.-J.; Lee, M.-C. A Study on Fire Risk Assessment of Monument and Historic Buildings in Taiwan; Ministry of Interior Architecture Institute: New Taipei City, Taiwan, 2011.

11. Chiang, P.-Y.; Huang, Y.-H. Fire Case Analysis of Tangible Cultural Heritages. J. Disaster Mitig. Rescue 2018, $19,19-40$.

12. Marrion, C.E. More effectively addressing fire/disaster challenges to protect our cultural heritage. J. Cult. Herit. 2016, 20, 746-749. [CrossRef]

13. NFPA 914: Code for the Protection of Historic Structures; NFPA: Quincy, MA, USA, 2019.

14. Himoto, K.; Tanaka, T. Development and validation of a physics-based urban fire spread model. Fire Saf. J. 2008, 43, 477-494. [CrossRef]

15. Shoseyama, S. Fire damage prediction method in earthquake damage prediction survey. J. Jpn. Fire Assoc. 2015, 65, 26-32.

16. Hsu, W.-S.; Huang, Y.-H.; Shen, T.-S.; Cheng, C.-Y.; Chen, T.-Y. Analysis of the Hsuehshan Tunnel Fire in Taiwan. Tunn. Undergr. Space Technol. 2017, 69, 108-115. [CrossRef]

17. Shen, T.-S.; Huang, Y.-H.; Chien, S.-W. Using fire dynamic simulation (FDS) to reconstruct an arson fire scene. Build. Environ. 2008, 43, 1036-1045. [CrossRef]

18. Huang, Y.-H. Fire Risk Assessment of Tangible Cultural Heritages and Historic Buildings. In Special Lecture on Disaster Prevention and Rescue of Culture Monuments; Fire Department: New Taipei City, Taiwan, 2019; pp. 17-32.

19. McGrattan, K.; McDermott, R.; Vanella, M. Fire Dynamics Simulator-User's Guide, Version 6.7.3; National Institute of Standards and Technology: Gaithersburg, MA, USA, 2019; pp. 5-11.

20. Huang, Y.-H. Fire Scene Reconstructed Simulation of Tangible Cultural Heritage-Taking Beigang Chaotian Temple as an Example. Police Sci. Bimon. 2020, 51, 45-60.

21. Chiang, P.-Y. Research on Performance-Based Design of Fire Safety System in Tangible Cultural HeritagesThe Case of Beigang Chao-Tian Temple. Master's Thesis, Central Police University, Taoyuan City, Taiwan, 2019; p. 97.

Publisher's Note: MDPI stays neutral with regard to jurisdictional claims in published maps and institutional affiliations. 